\title{
Implications of Openness: A Study into (All) the Growing Literature on Open Innovation
}

\author{
Eleni Giannopoulou', Anna Yström²*, Susanne Ollilaª ${ }^{3}$ Tobias Fredberg ${ }^{4}$, Maria Elmquist ${ }^{5}$
}

\begin{abstract}
Seven years after Chesbrough published the first book on open innovation; the field has literally exploded, and is continuing to do so at an increasing speed. Earlier overviews have analyzed the current status of the field at different points in time. The purpose with this paper is to take this research one step further and analyze gaps in the field as it has progressed up to date, and also discuss the managerial implications of that literature. All scientific literature (as found through major databases) published in English on open innovation has been analyzed qualitatively. The paper identifies current streams in the literature and identifies key issues that future research needs to solve. Compared to earlier reviews, we identify a shift in the direction that the research is taken. The paper discusses why this may be the case and speculates on the future of the field.
\end{abstract}

Key words: innovation management; research and development; content analysis; managerial implications; open innovation.

\footnotetext{
I Department of Technology Management and Economics. Chalmers University of Technology. SE-4I296 Gothenburg, Sweden. Telephone: + 30 210 5743712. E-mail: giannopo@student.chalmers.se

2* Department of Technology Management and Economics. Chalmers University of Technology. SE-4I296 Gothenburg, Sweden. Telephone: +46 (0)3I 772 8247. E-mail: anna.ystrom@chalmers.se (corresponding author)

${ }^{3}$ Department of Technology Management and Economics. Chalmers University of Technology. SE-4I296 Gothenburg, Sweden. Telephone: +46 (0)3I 772 84I4. E-mail: susanne.ollila@chalmers.se

${ }^{4}$ Department of Technology Management and Economics. Chalmers University of Technology. SE-4I296 Gothenburg, Sweden. Telephone: +46 (0)31 772 4425. E-mail: tobias.fredberg@chalmers.se

${ }^{5}$ Department of Technology Management and Economics. Chalmers University of Technology. SE-4I296 Gothenburg, Sweden. Telephone: +46 (0)3I 772 84I2. E-mail: maria.elmquist@chalmers.se
} 


\section{Introduction}

Despite the fact that "open innovation" has rapidly become one of the hottest topic in innovation management, comprehensive reviews of the state of the research in the field and its managerial implications are scarce. As the state of the research can have a major impact on how open innovation is practiced, it is very relevant to map the current situation as well as stake out future needs. Thus, this paper aims to be a valuable contribution to the further understanding of the growing field.

Open innovation started as a notion of the need to open up the innovation process outside the traditional boundaries of a firm. The mobility of knowledge makes it impossible to keep all the best talents and relevant knowledge within the companies; instead you need to look outside for new paths to innovation (Chesbrough, $2003 a, b)$. The term open innovation has since then come to be associated with several things in different contexts, from open source (West and Gallagher (2007)) to user co-creation (Franke and Piller 2004), user centered innovation and customer integration (von Hippel 2005) and distributed innovation (Sawhney and Prandelli 2000). The difficulty of pinpointing the essence of the term has lead to a scattered use, and some claim that there is little new about the phenomena (e.g. Piller and Walcher, 2006), supported by the fact that many of Chesbrough's classic examples are from the 1950s and forward.

The earlier reviews on open innovation by e.g. Fredberg, Elmquist and Ollila (2008) and Elmquist,
Fredberg and Ollila (2009) presented a categorization of themes in open innovation literature up until 2007. Since then, a lot has happened due to the fact that open innovation now is a buzz word used in many different contexts; therefore, this study takes its start in an update of the previously established themes in Olliterature, to see what new directions have been added and more specifically to analyze what impact this can have for managerial practices.

Due to its recent popularization, open innovation has become a serious interest for the industry, which of course is eager to find new ways to innovate. However, the guidance provided by the literature directed to managers are scattered and imprecise. A large portion of this paper is therefore devoted to summarize, analyze, and discuss the managerial aspects of openness. The paper starts with a description of the theoretical point of departure. It then goes into describing the method for selecting and categorizing the different publications that were included in the analysis. After that, the results are described. Theoretical conclusions as well as managerial implications are drawn. The paper ends with a discussion of the future of the field.

\section{Point of Departure}

Innovation models have changed over the years. From the simple linear model like the technology-push model of 1960s and the market pull model of 1970s - where the closed innovation paradigm dominated - to the most recent models where more complex, collaborative and more open practices are adopted.

\begin{tabular}{ll}
\hline Generation & Key Features \\
\hline $\begin{array}{l}\text { First and second } \\
\text { Third }\end{array}$ & $\begin{array}{l}\text { The linear models - need-pull and technology-push } \\
\text { Interaction between different elements and feedback loops among them - the } \\
\text { coupling model }\end{array}$ \\
Fourth & $\begin{array}{l}\text { The parallel lines model, integration with the firm, upstream with key suppliers and } \\
\text { downstream with demanding and active customers, emphasis on linkages and } \\
\text { alliances } \\
\text { Fifth }\end{array}$ \\
\hline
\end{tabular}

Table I. Rothwell's five generations of innovation models (1992) 
Under the closed innovation models firms had to do everything themselves. They relied on internal competences for the idea generation and the development of innovation projects and they used the firm's own distribution channels in order to commercialize them (Herzog 2008). So what has changed and why have firms started working under the open innovation paradigm? The mobility of skilled labor, the increasing presence of venture capital, the emergent high-tech start-ups and the role of university research and its linkages with industry are merely some of the factors that led to the open innovation paradigm (Costello et al. 2007).

This is the paradigm that Henry Chesbrough meant to explain when he first coined the notion of "open innovation" in 2003. He defined open innovation as a model in which "firms commercialize external (as well as internal) ideas by deploying outside (as well as inside) pathways to market" (H. W. Chesbrough 2003b). In other words, in the context of open innovation, the boundaries of the firm become permeable ( $U$. Lichtenthaler 2008c). The benefits of specialization and collaboration seem obvious today (Bughin et al. 2008). Companies have understood that they cannot merely rely on in-house capabilities and resources in order to innovate. In addition to that, they have realized that in order to maximize their profits from innovation they should not leave their own inventions "on the shelf" just because they cannot commercialize them themselves.

Taking all the above descriptions into consideration, following the open innovation paradigm means that value creation and value capture processes need to be reconsidered (Chesbrough and Appleyard 2007). Ownership of intellectual assets and protection of intellectual property used to be almost the sole source of competitive advantage. Alternatives to the model are now growing. Alliances between firms, distributed cocreation practices and collaborations with customers become more and more important. This calls for a reconsideration of some of the assumptions of classic business strategy (Chesbrough and Appleyard 2007).

But besides the theoretical dimension of open innovation, some discussions are also concentrated on the relevant managerial practices. When the concept emerged, the risk was expressed that maybe open innovation would be a managerial fad rather than a stable concept due to the absence of a sound framework (Faems 2008). Although this seems less and less to be the case, the need for effective managerial practices of open innovation is growing and it cannot be disregarded. The literature discussing "open innovation" has expanded rapidly over the last years, treating as diverse practical dimensions as strategy, leadership and organizational structure among others. As a result it offers a rich source of information for further discussion, analysis and potential suggestions for innovation managers.

\section{Methodology}

The results in this paper have been generated by systematic searches of literature and research on the topic of open innovation has been carried out in several sequential studies, in total covering the time period from 2003 up until June 30, 2009. The searches were made in selected databases which cover the field of social sciences, always with the same specific search terms and limitations. The databases and keywords are presented in Table 2.

In total 155 publications in English were found until June 30, 2009. Of these, 10 were books. Book reviews, reviews of other journal papers and journalism style columns as well as pure interviews were excluded from the analysis. The selection was limited to published material, and therefore also conference presentations and working papers were excluded. This resulted in us analyzing 134 publications.

\section{Thematic Analysis of Open Innovation Publications}

The categorization of the papers in the analysis departed from the categories created by Elmquist, Fredberg and Ollila (2009). They analyzed the literature from 2003 to November 2007 in an exploratory manner (reading, grouping, regrouping) and created seven larger themes. Their themes can be found in Table 3. 


\begin{tabular}{ll}
\hline Database & Search terms \\
\hline ISI Web of Knowledge & $\begin{array}{l}\text { The search term "open innovation" in title, keywords or abstract was used } \\
\text { in order to find relevant articles. Moreover the search was restricted to } \\
\text { Social Sciences Citation Index (SSCl). } \\
\text { The search term "open innovation" in title, keywords or abstract was used } \\
\text { in this database too in order to find relevant articles. Moreover the search } \\
\text { was restricted to "social sciences" only. }\end{array}$ \\
Scopus & $\begin{array}{l}\text { The search term "open innovation" in title, keywords or abstract was used } \\
\text { in this case too. } \\
\text { Management Journal } \\
\text { Amazon.com }\end{array}$ \\
& Also, the searches have included the Amazon website 6 for books with the \\
search term "open innovation" in the title.
\end{tabular}

Table 2. Databases covered in the search

\begin{tabular}{|c|c|c|}
\hline Coding ID & Category & Characteristic Words and Phrases \\
\hline I & $\begin{array}{l}\text { Exploring the notion of } \\
\text { Open Innovation }\end{array}$ & $\begin{array}{l}\text { Open }{ }^{6} \text { Innovation, concept, openness, open business model, inbound } \\
\text { innovation, outbound innovation, exploration, exploitation and others }{ }^{7}\end{array}$ \\
\hline 2 & Business Models & $\begin{array}{l}\text { Business model, create value, capture value, licensing, spinoff, } \\
\text { outsourcing, partnership, alliance, collaboration }\end{array}$ \\
\hline 3 & $\begin{array}{l}\text { Organizational Design } \\
\text { and Boundaries of the } \\
\text { Firm }\end{array}$ & $\begin{array}{l}\text { Organizational design, boundaries, outside the firm, external assets, } \\
\text { external knowledge, structures, mechanisms, organizational set-up }\end{array}$ \\
\hline 4 & Leadership and Culture & $\begin{array}{l}\text { Leadership, project leader, culture, mindset, relationship(s), } \\
\text { relationship management, trust, control, respect, manager(s) }\end{array}$ \\
\hline 5 & Tools and Technologies & $\begin{array}{l}\text { Tools, technologies, internet tools, solution providers, customers, } \\
\text { interface, coordinating tools or technologies, liberating tools or } \\
\text { technologies, idea competition, customer creativity, allowing/including } \\
\text { tools or technologies, sources of ideas, customer interaction, } \\
\text { integrate customers, collective invention, avatar, virtual world, co- } \\
\text { creation, lead users }\end{array}$ \\
\hline 6 & $\begin{array}{l}\text { IP, Patenting and } \\
\text { Appropriation }\end{array}$ & $\begin{array}{l}\text { IP, intellectual property, IPR, property rights, intellectual assets, } \\
\text { protection of IP, technology assets, free revealing, secrecy, selective } \\
\text { revealing, appropriability, regime }\end{array}$ \\
\hline 7 & $\begin{array}{l}\text { Industrial Dynamics and } \\
\text { Manufacturing }\end{array}$ & $\begin{array}{l}\text { Industry, evolutionary economics, economics, innovation systems, } \\
\text { technological regime, regime regional innovation system(s), cluster(s), } \\
\text { regional, mega-centers, manufacturing, lean production, } \\
\text { competitiveness, technology policy, policy(ies), economic development }\end{array}$ \\
\hline
\end{tabular}

Table 3. Categories provided by Elmquist, Fredberg and Ollila (2009) with keywords and coding keys

\footnotetext{
${ }^{6}$ www.amazon.com

7 Category I: "Exploring the notion of Open Innovation" is very broad. Thus it is more the overall judgment of the article than the presence of certain words that determined the classification of an article into this category.
} 
For this paper, the categories published by Elmquist, Fredberg and Ollila (2009) were developed further to better match the current state of research. To do this, content analysis was performed on the publications from November 2007 up until 30 June 2009, and the earlier publications were checked for their fit with the new categories that emerged.

Content analysis is an approach to analyze documents and texts, in order to quantify the content in terms of predetermined categories and in a systematic and replicable manner (Bryman and Bell 2007). The method consists of three steps (Figure I); first, selecting the media type and the suitable dates. Second, what should be coded in the analysis process needs to be decided. This could be words, significant actors, dispositions or subjects and themes; ultimately it is the research question that is decisive. The third step is the actual coding, which is done with a coding schedule and manual. The schedule consists of all the data that needs to be gathered, and the coding manual contains more specific instructions to specify the classification categories (Bryman and Bell 2007).

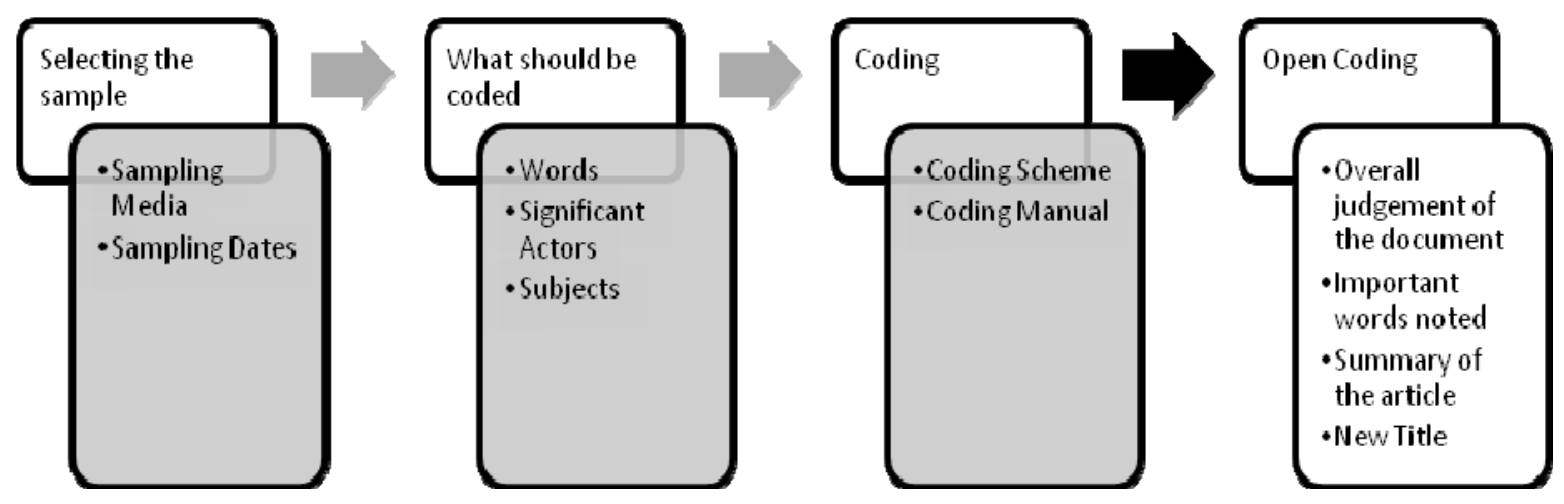

Figure I. The process of modified content analysis used in this study

The coding manual was based on the categories created by Elmquist et al (2009) and completed with keywords and synonyms in order to identify these categories (Table 3). The coding scheme and the coding manual can be found in Appendix A. Special attention was given to the title, abstract, purpose and conclusions as these were regarded to contain the essentials of the publications.

In this study, the process of content analysis coding was also complemented by open coding, which all the publications went through (Figure I). Open coding is not only an overall judgment of the document, but also finding synonyms of the words used in the first, structured step of analysis8 (the words in italics). Open coding also resulted in the identification of new major

\footnotetext{
8 The list of words and phrases provided in the coding scheme was not complete beforehand but was dynamically created throughout the analysis process.
}

subjects not covered by the previously defined categories. It should be noted that some documents were classified in several categories, as they dealt with several issues.

\section{Identifying Managerial Implications}

As a specific focus, managerial implications mentioned in the publications on the level of practices and recommendations were sought for in the open coding procedure. Thus important managerial implications were also noted down in the relevant part of the coding schedule. In the first step the categorization of managerial implications followed the final classification of the Open Innovation literature. Then the managerial implications were further grouped to four major categories, making them more practically applicable, relevant and useful to innovation managers. 


\section{The Development of New Categories}

The results are described here to provide an understanding of where the field is going. Figure 2 illustrates the development of the field. On its top left side, it shows the earlier categories developed by Fredberg et al. (2008) and Elmquist et al. (2009). On its

\section{Previous Categories}

Exploring the notion of Open Innovation

Business Models

Organizational Design and Boundaries of the Firm (2)

Leadership and Culture (4)

Tools and Technologies

IP, Patenting and Appropriation (6)

Industrial Dynamics and Manufacturing (8) top right side, it shows the new categories and how the earlier categories "Leadership and Culture" and "Industrial Dynamics and Manufacturing" were developed into "the Human Factor in Open Innovation" and "Collaborating with academia and Government Policy", respectively. The box in the bottom of the Figure 2 lists the new categories.

\section{Recent Categories \\ Open Innovation: the development of the Concept (I) \\ Open Strategy (3) \\ The Human Factor in Open Innovation (4) \\ Communities for Distributed co-Creation with Customers and other Collaborating Actors (5) \\ Innovation Intermediaries: A new Business Model Arising}

(7)

Collaborating with Academia (8)

Government Policy (8)

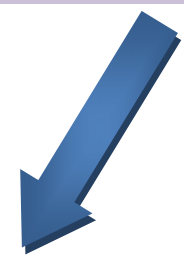

\section{New Classification}

(I) Open Innovation: the development of the Concept

(2) Organizational Design and Boundaries of the Firm

(3) Open Strategy

(4) The Human Factor in Open Innovation, Culture and Leadership

(5) Communities for Distributed co-Creation with Customers and other Collaborating Actors

(6) IP, Patenting and Appropriation

(7) Innovation Intermediaries: A new Business Model Arising

(8) The triple helix: Academia, Industry, Government Policy

Figure 2. Development of the new categories

The point of developing new categories is of course to mark the development of the field. Through structured content analysis, it was possible to discover the most important current dimensions/categories of the open innovation research published to date. Table 4 shows the different keywords that characterizes the new categories. The table is provided to give clear oversight to how we coded the data and hence to form the basis for future research. 


\begin{tabular}{|c|c|}
\hline Categories & Keywords \\
\hline OI: the development of the Concept & $\begin{array}{l}\text { The concept of } \mathrm{Ol} \text {, the notion of } \mathrm{Ol} \text {, dimensions of } \mathrm{Ol} \text {, } \\
\text { inside-out process, outside-in process, exploration, } \\
\text { exploitation, model, framework a.o.9 }\end{array}$ \\
\hline $\begin{array}{l}\text { Organizational Design and Boundaries of the } \\
\text { Firm }\end{array}$ & $\begin{array}{l}\text { Organization, organizational setup, organizational units, R\&D } \\
\text { organization, mechanisms, structures, process, inside-out } \\
\text { process, outside-in process, inward process, outward } \\
\text { process, product development process, stage gate model, } \\
\text { stages, capabilities, competencies, resources, absorptive } \\
\text { capacity, relative capacity, } \mathrm{TCl} \text { capabilities. }\end{array}$ \\
\hline Open Strategy & $\begin{array}{l}\text { strategy, strategic choice, strategic approach, technology } \\
\text { exploration, technology exploitation, out-licensing, R\&D } \\
\text { alliances/collaborations, partnerships, academia, } \\
\text { communities. }\end{array}$ \\
\hline $\begin{array}{l}\text { The Human Factor in OI, Culture and } \\
\text { Leadership }\end{array}$ & $\begin{array}{l}\text { Leader, leadership, culture, mentality, mindset, cultural } \\
\text { change, human factor, employees, customers, communities, } \\
\text { motivation, motives, incentives, teamwork, team }\end{array}$ \\
\hline $\begin{array}{l}\text { Communities for Distributed co-Creation } \\
\text { with Customers and other Collaborating } \\
\text { Actors }\end{array}$ & $\begin{array}{l}\text { (Online) community, brand community, participations, OSS, } \\
\text { open source, open standards, customer, customer } \\
\text { involvement, customer participation, virtual worlds, avatars, } \\
\text { co-creation }\end{array}$ \\
\hline IP, Patenting and Appropriation & $\begin{array}{l}\text { IP, intellectual property, IPR, intellectual property rights, } \\
\text { technology assets, knowledge, sharing, free revealing, } \\
\text { selective revealing, appropriability, regimes, patent, patent } \\
\text { system, IP auctions, IP protection, secrecy. }\end{array}$ \\
\hline $\begin{array}{l}\text { Innovation Intermediaries: A new Business } \\
\text { Model Arising }\end{array}$ & $\begin{array}{l}\text { Technology or innovation intermediaries, knowledge } \\
\text { brokers, solution providers, solver brokers, solution } \\
\text { brokers, solution seekers, brokerage, technology } \\
\text { transactions. }\end{array}$ \\
\hline $\begin{array}{l}\text { The Triple Helix: Industry, Academia and } \\
\text { Government Policy }\end{array}$ & $\begin{array}{l}\text { Industry, regional innovation systems, clusters, academia, } \\
\text { universities, industry-academia linkages, government, policy, } \\
\text { policy makers, innovation systems, innovation regimes, global } \\
\text { innovation networks. }\end{array}$ \\
\hline
\end{tabular}

Table 4. Description of the new categories with the keywords attached to them

\footnotetext{
${ }^{9}$ In this category we could add every keyword related to the Ol context that are noted in the rest of the categories as it is too general to be identified merely by some words.
} 


\section{Results}

Here the current classification of the open innovation literature is presented as a result of the content analysis.

\section{Open Innovation: The Development of the Concept $^{10}$}

Recently there have been some noteworthy attempts to further develop the theoretical background of the OI concept through models and frameworks. Most of the efforts are focused on determining in depth the two dimensions of $\mathrm{Ol}$; the inside-out and the outside-out. Sandulli and Chesbrough (2009) define the two sides of open business models; the Buying and the Selling side corresponding to the outside-in and the inside-out technology transaction. According to which of these two sides the firm is adopting there are four relevant business models: open business models, partially open business models - the buying side, partially open business model - the selling side, closed business model.

Moreover, Lichtenhalter (2008a) tries to establish a framework for the external technology commercialization process comprising of the following five stages: planning, intelligence, negotiation, realization and control. With the same reasoning and only for the inward process (or external technology exploitation) Slowinski et al. (2009) came up with the "Want, Find, Get, Manage" model.

The need to balance between the two dimensions is also outlined by Harryson (2008) and his networktheory based model as well as by Cassiman and Valentini (2009) and their attempt to relate the strategy to the structure of the firm and determine the relevant exploitation or exploration choice.

\section{Organizational Design and Boundaries of the Firm}

Special organizational needs derive from the $O I$ paradigm. Broring and Herzog (2008) argue that

10 Due to the generality of this category some of the issues presented here may also belong in the following categories, taking another perspective according to the special topic they are addressing. organizational implications differ between open and closed innovation. Herzog (2008) argues that the organizational design should balance the exploration vs. exploitation dilemma. He proposes a built in ambidexterity in the organizations which however does not imply that they are loosely coupled.

Broring and Herzog (2008) argue that new business development (NBD) in a separate unit plays an important role. This unit should balance between exploration (seeking radical innovations) and exploitation (seeking incremental innovation) and this balance should exist both on a company level and inside the unit (Broring and Herzog 2008).

Furthermore $\mathrm{Ol}$ also challenges the classical resource based view according to which internal capabilities are among the firm's biggest competitive advantage. Broring and Herzog (2008) argue that depending on the degree of newness of the innovation which is pursued and the resulting competence gaps, there are different needs to bring knowledge in from outside the organization, and hence different needs for the organization to be open. Cassiman and Valentini (2009) argue that the extent to which a firm will rely to internal or external competencies to perform R\&D is a critical choice.

According to Herzog (2009) Ol needs technology sensing and response and risk taking capabilities. There is a need to develop the technology related absorptive capacity which turns the technological knowledge to application knowledge but also the market related absorptive capacity which turns the application knowledge to technological knowledge (Herzog 2008).

\section{Open Strategy}

"As knowledge has become the key resource, OI needs to be embedded in an overall business strategy that explicitly acknowledges the potential use of external ideas, knowledge and technology in value creation" (OECD 2008, pp.II). Ol can no longer be perceived as an ad-hoc activity but as a strategic choice. For example, external acquisition/exploitation is a coming necessity for firms to keep up with competitors (Lichtenthaler 2008c). Lichtenthaler (2008a) identifies technology out licensing as a major technology exploitation practice. The need of having an explicit strategy for technology exploitation that balances the 
risks and benefits rather than having just "planned emergence" is outlined (Lichtenthaler 2008b). Slowinski et al. (2009) argue that the firm's own strategy depends on the innovation activities. There are two types of technology transactions: technology acquisition and technology exploitation. These can take place internally or externally. Lichtenthaler (2008c) thinks of the two as the main dimensions of a firm's strategic approach to OI. In the same context Herzog (2008) identifies also the exploration vs. exploitation duality of a firm's innovation strategy and he compares it to the radical vs. incremental innovation dilemma.

For the technology exploration strategies, Bessant (2008) proposes that firms need to adopt strategies that will help to keep the firm updated in new technology trends such as participation in communities, the use of scouts and technology brokers, supporting internal capabilities of creativity, developing corporate venturing/entrepreneurship capabilities and leveraging creativity tools.

Finally, other strategies concern collaboration with communities, other companies (alliances) and customers, suppliers, government and universities Morgan and Finnegan (2008); all these apply for both exploration and exploitation strategies.

\section{The Human Factor in OI, Culture and Leadership}

It is people who push, modify or drop the innovation (Herzog 2008). From simple employees to middle managers, project managers and top management, it is people that determine the firm's degree of openness and the culture of the company (Herzog 2008).

When the human factor is discussed naturally issues of teamwork and motivation also arise. Gemunden, Salomo and Hölzle (2007) argue that professionalization of cross-functional teamwork is as important as effective innovator roles and a good innovation system for the success of the innovation process. On the level of motivation, supporting innovative behavior and creating an environment that permits constructive dispute are important Herzog (2008). Herzog (2008) argues that extrinsic as well as intrinsic motivation is needed whether we have to deal with an Open or a Closed Innovation model.
But people also make the culture of a firm and cultural change is essential to innovation activities (Slowinski et al. 2009). The most prominent publication on the cultural aspects of $\mathrm{Ol}$ is a dissertation by (Herzog 2008). Herzog (2008) argues that Open and Closed innovation cultures need to be different. OI needs a risk taking culture. The firm should be ready to respond to exploration and exploitation needs by adopting an ambidextrous mentality (Vanhaverbeke et al. 2008).

It is the management's responsibility to bring in cultural change, new thinking and clear mandates to "access external innovation" (Slowinski et al. 2009). Herzog (2008) discusses how organizational factors affect the employee's reaction to $\mathrm{OI}$ more than individual personalities and identifies the major role of leadership in OI (Herzog 2008). Leaders should be able to overpass the Not Invented Here syndrome as well as the Only Used Here syndrome. Finally management must lead the way to the change of innovation culture where the combination of internal and external sources of innovation is essential (Slowinski et al. 2009).

\section{Communities for Distributed co-Creation with Customers and Other Collaborating Actors}

In order to explain the trend of a great number of organizations using not only customers but also suppliers, independent specialists in co-creating new products and services Bughin et al. (2008) introduce the term of distributed co-creation (Prahalad and Ramaswamy 2000). This is done often through communities.

Bretschneider et al. (2008) introduce the concept of community (often online) for innovation consisting of customers and company members which support the company throughout the innovation process. More often, firms are involved either directly (as members) or indirectly (by paying money to members) in the communities (West and Lakhani 2008). The requirements of such a community are organizational and technical.

According to Dahlander et al. (2008a) the benefits of communities are: creating brand loyalty, using the customers' creativity, advertising the product and its value. However some challenges are also mentioned such as the difficulty of managing and controlling these 
communities and the people participating in them (Dahlander et al. 2008).

Bergman, Jantunen and Saksa (2009) believe that communities are so successful in $\mathrm{Ol}$ activities because the commitment of all actors to a certain goal is essential for OI. However, they pose a matter of incentives is it benefits or benevolence that drives the community's members? Wanting to find out what motivates customers to take part in such communities Fuller et al. (2008) investigate how passion for the brand, affiliation to the brand community and trust in the brand affects the willingness to engage in a company's innovation process.

Besides customer communities there are also the open standards community discussed by (Waguespack and Fleming 2009) and open source software (OSS) communities (Morgan and Finnegan 2008). This links to an enormous field of research which is highly related to the open innovation research but is not in focus for this paper.

\section{IP, Patenting and Appropriation}

It is more than evident that in the context of OI where collaborations are established, technology assets are being exchanged and commercialized within the emerging technology marketplaces issues of IPR arise (Lee and Lee 2009). In a report, the OECD argues that although several companies still use IPR mainly in a defensive way there are companies who engage in OI practices and are willing to share their IP in an attempt to use their intellectual assets proactively (OECD 2008).

Pénin and Wack (2008) examine patents in the context of "open science". According to them, patents are useful but complex instruments that should not merely be treated as tools of exclusion. The authors propose a so called "free-libre" open source software model -the FLOSS Model- and apply it to biotech industry. They argue that their work goes beyond the patent issue to the global sharing of research.

Henkel (2009) takes the same approach of "open science" as Pénin and Wack (2008) on the issue of IP in his article about open source software developers. He argues that companies should rethink their practices on
IP and proposes a more positive attitude towards revealing the results of the research in order to better share the benefits of $\mathrm{Ol}$.

Finally researchers mention that the different strategies of OI require particular IP management. Slowinski and Zerby (2008) deal with the challenges that arise regarding IP in collaborations between companies; for instance on how to apply for patents when they derive from a collective invention (Slowinski and Zerby 2008). Bughin et al. (2008) discusses the issue of IP management in communities. Lichtenhalter (2008a) places the issue of intellectual property in the "technology intermediaries" context where IP rights can be a significant barrier to firms using intermediary services and proposes the establishment of appropriability regimes.

\section{Innovation Intermediaries}

Innovation intermediaries help innovators use external knowledge and inventors to find a market to sell their ideas (Lee and Lee 2009). According to Lee and Lee (2009) there are two kinds of technology intermediaries agents and brokers. Feller et al. (2008a) on the other hand differentiate between solution brokerage and solver brokerage in the mediated services.

Innovation intermediaries also act through internet marketplaces where transactions between solution seekers and providers take place. However hopes were not fulfilled for these internet market places (Lichtenhalter and Ernst 2008a). Another example presented by Lee and Lee (2009) is an auction of patents, trademarks and copyrights. Accordingly Terwiesch and Xu (2008) present II who establish innovation contests where a firm (the seeker) facing an innovation-related problem (e.g. a technical R\&D problem) posts this problem to a population of independent agents (the solvers) and then provides an award to the agent that generated the best solution.

According to Lee and Lee (2009) II are very important actors in the technology market because they manage win-win transactions. Moreover firms can overcome technology market inefficiencies by relying on II such as consulting companies and internet platforms (Lee and Lee 2009; Lichtenhalter and Ernst 2008a; U. Lichtenthaler and Ernst 2008b). Some disadvantages are 
also presented by Lichtenhalter and Ernst (2008a) focusing on intellectual property rights which can always be a challenge in these technology transactions.

\section{The Triple Helix: Industry, Academia and Government Policy"}

Due to rapid changes in technology not only firm boundaries but also industry borders are shifting, thus new organizational structures are needed (OECD 2008). OECD's (2008) book addresses the industry level of Ol thoroughly, where it is being argued that differences among industries are significant on how they adopt Ol. Cassiman and Valentini (2009) believe that the R\&D management differs among firms in a given industry but also among industries. Finally according to Tether and Tajar (2008) there are differences between service and manufacturing firms.

Discussion is also made on academia linkages with the industry. Perkmann and Walsh (2007) describe different kinds of university-industry links and identify the research partnerships and the contract research and consulting as the most important links. The trend of increased patenting from universities and the problems it could create in the relationship with companies which do not seek to publish their research is also discussed (Mowery 2009).

Since innovation is critical to the country's competitiveness (Chen 2008) there is an adequate amount of articles presenting policies and giving recommendation to policy makers on how to deal with Ol. For instance (León 2007) describes short term and long term policy instruments available today supporting R\&D for a shorter or longer period of time. (Young et al. 2008) argue that policy-makers have recognized the importance of external knowledge by establishing publicly funded R\&D centers (PRCs), in order to stimulate innovation spillovers and industry-science links.

II The name of this category was paraphrased from Costello et al. G.J. Costello et al., 'The Triple Helix, Open Innovation, and the Doi Research Agenda', IFIP International Federation for Information Processing, 235 (2007), 463-68.according to whom the triple helix refers to three important collaborating actors for Ol; namely government, academia and firm.

\section{The Managerial Implications of Openness}

Besides the theoretical contributions this study also presents some important practical contributions in terms of managerial implications, both on the level of practices and awareness. The recommendations are addressed to every level of managers but they are most relevant to the top management since they get to influence multiple dimensions of the innovation process management. The recommendations are grouped into four main categories.

\section{"Open" Strategy and Organization}

Chesbrough and Appleyard (2007) argue that the biggest challenge firms are facing is getting over the determinants of traditional business strategy. They need to embrace strategic approaches that address both the inside in and the outside out processes of Ol. Exploration and exploitation does not have to be contradicting; the right balance has to be found.

For exploration activities Slowinski et al. (2009) suggest that it is important for the firm to define accurately what they want to access externally. Thus managers should be alert to monitor the environment and react early on possible opportunities. Bessant (2008) proposes some practices towards this approach; namely sending out technology scouts, exploring multiple futures online, using creativity tools and techniques and leveraging brokers among others. Selecting the right knowledge sourcing method can be challenging from the management of collaborators and the IP issues to the non-fit of technology or the risk of commercialization failure (Kang and Kang 2009).

On the other hand external technology acquisition/exploitation is a coming necessity for firms to keep up with competitors (Kirschbaum 2005). Managers should bear into mind that exploitation requires more closed and rigid approaches to R\&D management. A way for effective external technology exploitation is to incorporate it into corporate strategic planning as proposed by Lichtenthaler (2008b). The external technology commercialization process can no longer be perceived as an ad-hoc activity. For instance the "integrated technology roadmaps" proposed by Lichtenthaler (2008b) or "functional markets" can be useful tools. 
Both the establishment of a systematic external technology exploitation process as well as a systematic external technology exploration process rather than ad-hoc activities is essential (Lichtenthaler 2008d). Of course this has implications for the organizational side as well. If managers decide to adopt a certain "open" strategy they need to establish the necessary organizational structures and processes and develop the relevant capabilities that will help in the pursuance of this strategy.

In the organizational side of $\mathrm{OI}$ a number of proposals regarding structures, mechanisms and processes constitute valuable help in enabling the $\mathrm{OI}$ process. For instance an open information infrastructure proposed by Kuschel (2008), network boards suggested by Wincent et al. (2009) or treating project management under the OI paradigm. Cooper's $(2008 ; 2009)$ suggestion to adjust their stage gate model to include the $\mathrm{Ol}$ paradigm throughout the whole process of new product development, scenarios and GDSS to complement the heuristic scenario development process to support knowledge creation in the OI process (Bergman et al. 2009) are also useful suggestions.

However what is most important is the ambidexterity that should be present in the organizational set-up. Managers should understand that separating radical and incremental innovation into different organizational units can be beneficial. Thus capabilities of both external technology sourcing and commercialization should be developed. For both these dimensions of the $\mathrm{Ol}$ process the absorptive capacity (both its technological and market dimension) is extremely important (Herzog 2008). Moreover for the challenge of identifying technology commercialization (TC) opportunities firms need to develop proficient $\mathrm{TCl}$ competencies in order to achieve the benefits of external technology transfer (Lichtenthaler et al. 2008).

\section{Leverage Leadership to Motivate Employees and Bring in Cultural Change}

A large number of researchers agree that cultural change is essential to innovation activities. Management must lead the way to the change of innovation culture where the combination of internal and external sources of innovation is essential by adopting an ambidextrous mentality (Wim Vanhaverbeke et al. 2008). An answer to the challenge of excessive ambidexterity can be tackled by sound relationship management ( $\mathrm{He}$ and Wong, 2004). In any way leadership should balance between exploration and exploitation by navigating successfully from creation to commercialization (Harryson 2008).

Moreover it is the leader's responsibility to find and fight the resistance to change. They need to persuade the technical staff that, although the procedure is often hard and time consuming, it is worthwhile. The message should be clear: "sourcing external innovation does not compete nor substitutes internal activities". The same should be done with middle managers and incentives must be given in order to overcome unwanted joint decision-making and time consuming activities that are not needed when working internally (Slowinski et al. 2009).

The leader should also support and motivate the people that are involved in the OI process with every mean they have. Effective relationship building can be an important tool for the leader in order to deal with relations inside and outside the firm and manage the creativity, process or transformation networks (Harysson, 2008). In order to motivate employees Herzog (2008) proposes that the leader should give incentives extrinsic such as financial rewards but also intrinsic such as appreciation. It is the management's responsibility to build a system that favors along with internal also external innovation. Moreover leaders should pass on to employees the message of success. The use of success stories from the company's history but also from other companies can motivate employees and give valuable lessons (Slowinski et al. 2009).

\section{Creating Value from External Relationships: Alliances, Communities, Intermediaries and Academia}

A common message of the literature is: Do not be afraid to collaborate! Value creation forces are found in creative individuals, innovation communities, collaborative initiatives with other companies, suppliers government organizations and academia (Chesbrough and Appleyard, 2007; Morgan and Finnegan 2008).

Communities can be a rich source of ideas for innovating companies. Even though opening up the innovation process to customers might seem risky sometimes it is not worth imposing barriers to the clients since they can be a really valuable source of innovation (Braun and Herstatt 2008). Collaborating with customers throughout all the stages of innovation and involving them from the early research stages to commercialization can be very beneficial 
(Bretschneider et al., 2008). However it is not enough to merely collect the market feedback from customers; managers should not ignore the possibility of users as a source of product improvements or even radical innovations (Braun and Herstatt 2008).

In customer communities it is important to build a dynamic interaction between the firm and the community in order to bridge any knowledge gaps that may prevent the creativity process. The manager should balance between control and creativity by delegating authority and control from the firm to the community (Di Gangi and Wasko 2009).

In order to ensure inspired participation the firm needs to give them incentives; not only financial (Füller et al. 2008). Building feelings of trust and altruism, enhancing brand affinity and fame, offering fun and giving space for creativity can be effective practices (Bughin et al. 2008). Moreover structuring problems or breaking them down to enable parallel work and allow for creative participation makes the collaboration easier.

In the case of innovation intermediaries there are several ways for managers to enhance their benefits from relying on innovation intermediaries in the market of technologies such as complementing intermediary services with internal activities and inter-firm networks (Lichtenhalter and Ernst 2008a). Firms should rely on intermediary services as a complement rather than as a substitute for internal resources (Lichtenthaler and Ernst 2008b). A manager should use diverse types of knowledge providers which complement each other (Tether and Tajar 2008). Moreover developing internal dynamic capabilities of coordinating intermediary services and supporting actively the technology transfer is very beneficial (Lichtenhalter et al. 2008a). In order for intermediary services to lead to advantage relative to competitors, managers should consider transferring more than merely non-core technologies (Lichtenthaler and Ernst 2008b).

Finally the linkages with academia are equally important as they do not merely contribute to the innovation process by delivering inventions but they also offer creative ways of solving problems, accessing students, gaining "windows" on emerging technologies and gaining knowledge for specific innovations (Perkmann and Walsh 2007).

\section{Intellectual Property (IP) Management}

Managers should reconsider their attitude towards IP management and allow more openness than they dear to (Henkel 2009). The literature suggests that there should not be any reluctance regarding filling patents; patents are useful tools that can be used in favor of Ol. Adopting the principles of "Open science" (Penin and Wack 2008) or "free revealing" (Henkel 2009) may be extremely beneficial for the company.

In the same context the participation in innovation contests and IP auctions for finding valuable solutions (Terwiesch and Xu 2008) is recommended. Although they may seem like they are deterring innovation they actually can boost it (Lee and Lee 2009). Attention should be made however to opportunistic behaviors and patent trolls though (Lee and Lee 2009).

Furthermore the appropriability of IP resulting from any collaborative activity can be problematic. For instance the IP management in the case of co-creation in communities is very important. Clear rules need to be established from the beginning so that problems with appropriation do not arise (Bughin et al. 2008).

In the case of collaboration between companies managers should not start collaborating without the appropriate agreements in place. Another suggestion is to avoid having IP ownership depend on inventorship. Moreover when filling a patent resulting from a co-creation with another company it could be useful to let the other part go over it before submitting it.

Attention should be given also to the collaboration with universities since they do not share the same mentality with most of the companies about publishing and sharing intellectual assets. Moreover the relationship with intermediaries may result in problems with the appropriability of IPR thus managers should consider establishing a relevant regime as a solution (Lichtenhalter and Ernst 2008a).

\section{Discussion on the Managerial Implications}

The topics of strategy and organization require practical approaches and we have seen some important contributions in the literature. We should note however that an integrated organizational setup has not been 
presented yet. Of course the processes proposed for structuring the inward and outward technology transactions or the adapted version of the stage gate system is significant. Essential is also the specific definition of the capabilities needed for Ol. As far as the strategy is concerned I believe that the strategic approaches presented are feasible and should be considered from managers. Especially when it comes to the external technology commercialization Lichtenthaler's contribution is significant.

The issue of leadership although marginally treated provides some important recommendations especially on how to change the culture in the organization and motivate and influence employees. However we have already in the discussion detected omissions that need to be addressed in order to successfully lead the complex innovation paradigm.

A lot of managerial implications were given to communities and their effective management. Communities have started to be seen as a part of the organization thus they need to be managed as such. The same thing goes for intermediaries, although since this is a new relation for the company and experience is limited recommendations are mostly on the theory level. For the academia linkages there is not so much discussion as the issue is treated as trivial since these constitutes a rather old method.

Although IP issues are crucial for OI, surprisingly there is a lack of effective IP management practices in the literature. This is a topic that requires more attention as it is one of the major barriers to Ol. Maybe the open science and the sharing is the answer. However the challenge to persuade managers that the value they are losing is significantly less than the value they are creating for their company is present. Maybe this is after all what the major challenge of $\mathrm{Ol}$; to make managers believe in the Open paradigm when for years they have protected and preserved their intellectual assets with every mean they had.

\section{References}

BERGMAN, J., Jantunen, A., Saksa, J. M. (2009). Enabling open innovation process through interactive methods: Scenarios and group decision support system. International Journal of Innovation Management, I3, I39-156.
BESSANT, J. (2008). Dealing with discontinuous innovation: The European experience. International Journal of Technology Management, 42, 36-50.

BRAUN, V., Herstatt, C. (2008). The freedom-fighters How incumbent corporations are attempting to control user-innovation. International Journal of Innovation Management, 12, 543-572.

BRETSCHNEIDER, U., Huber, M., Leimeister, J. M., Krcmar, H. (2008). Community for Innovations. In Leon, G., Bernandos, A., Casar, J., Kautz, K. \& Degross, J. (Eds.) Open IT - Based Innovation: Moving Towards Cooperative IT Transfer and Knowledge Diffusion. Boston: Springer

BRORING, S., Herzog, P. (2008). Organizing new business development: Open innovation at Degussa. European Journal of Innovation Management, I I, 330-348.

BRYMAN, A., Bell, E. (2007). Business Research Methods, Oxford University Press.

BUGHIN, J. R., Chui, M., Johnson, B. (2008). The next step in open innovation. McKinsey Quarterly.

CASSIMAN, B., Valentini, G. (2009). Strategic organization of R\&D: the choice of basicness and openness. Strategic Organization, 7, 43-73.

CHEN, C.-K. (2008). Causal modeling of knowledge-based economy. Management Decision, 46, 50I-5I4.

CHESBROUGH, H. W. (2003). The new imperative for creating and profiting from technology, Harvard Business Publishing.

CHESBROUGH, H. W. (2003b). The era of open innovation. MIT Sloan Management Review, 44, 35-4I.

CHESBROUGH, H. W., Appleyard, M. M. (2007). Open innovation and strategy. California Management Review, 50, 57-76.

COOPER, R. G. (2008). Perspective: The stage-gates ideato-launch process - Update, what's new, and NexGen systems. Journal of Product Innovation Management, 25(3), 213-232. 
COOPER, R. G. (2009). How companies are reinventing their idea-to-launch methodologies. Research-Technology Management, 52(2), 47-57.

COSTELLO, G. J., Donnelan, B., Gleeson, I., Rochfor, C. (2007). The triple helix, open innovation, and the DOI research agenda. IFIP International Federation for Information Processing, 235, 463-468.

DAHLANDER, L., Frederiksen, L., Rullani, F. (2008a). Online Communities and Open Innovation: Governance and Symbolic Value Creation. Industry and Innovation, 15, II5-123.

DI GANGI, P. M., Wasko, M. (2009). Steal my idea! Organizational adoption of user innovations from a user innovation community: A case study of Dell IdeaStorm. Decision Support Systems.

ELMQUIST, M., Fredberg, T., Ollila, S. (2009). Exploring the field of open innovation: a review of research publications and expert opinions. European Journal of Innovation Management, I2(3), 326-345.

FAEMS, D. (2008). Open Innovation: Researching a New Paradigm \&\#x2013; By H. Chesbrough, W. Vanhaverbeke and J. West. Creativity and Innovation Management, 17(4), 334-335.

FELLER, J., Finnegan, P., Hayes, J., O'Reily, P. (2008a). Governance Structures for Open Innovation: A Preliminary Framework. In Leon, G., Bernandos, A., Casar, J., Kautz, K. \& Degross, J. (Eds.) Open IT - Based Innovation: Moving Towards Cooperative IT Transfer and Knowledge Diffusion. Boston: Springer

FRANKE, N., Piller, F. (2004). Value creation by toolkits for user innovation and design: The case of the watch market. Journal of Product Innovation Management, 2I, 40I-4I5.

FREDBERG, T., Elmquist, M., Ollila, S. (2008). Managing Open Innovation - Present Findings and Future Directions. VINNOVA Report VR 2008:02. Chalmers University of Technology.

FULLER, J., Matzler, K., Hoppe, M. (2008). Brand Community Members as a Source of Innovation. Journal of Product Innovation Management, 25, 608-619.
GEMUNDEN, H. G., Salomo, S., Hölzle, K. (2007) Role Models for Radical Innovations in Times of Open Innovation. Creativity and Innovation Management, 16, 408421 .

HARRYSON, S. J. (2008) Entrepreneurship through relationships - Navigating from creativity to commercialization. R\&D Management, 38, 290-310.

HE, Z.-L., Wong, P.-K. (2004). Exploration vs. Exploitation: An Empirical Test of the Ambidexterity Hypothesis Organization science, 15(4), 48I-494.

HENKEL, J. (2009) Champions of revealing-025EFthe role of open source developers in commercial firms. Industrial and Corporate Change, 18, 435-47I.

HERZOG, P. (2008) Open and Closed Innovation - Different Cultures for Different Strategies, Gabler Edition Wissenschaft.

KANG, K. H., Kang, J. (2009). How do firms source external knowledge for innovation? Analysing effects of different knowledge sourcing methods. International Journal of Innovation Management, I3, I-I7.

KIRSCHBAUM, R. (2005) Open innovation in practice. Research-Technology Management, 48, 24-28.

KUSCHEL, J. (2008) The Vehicle Ecosystem. IN LEON, G., BERNANDOS, A., CASAR, J., KAUTZ, K., Degross, J. (Eds.) Open IT - Based Innovation: Moving Towards Cooperative IT Transfer and Knowledge Diffusion, Boston: Springer.

LEE, Y. G., Lee, J. H. (2009). Different characteristics between auctioned and non-auctioned patents. Scientometrics: I-14.

LEON, G. (2007). Cooperative models for information technology transfer in the context of open innovation. IFIP International Federation for Information Processing (235), 43-6I.

LICHTENTHALER, U. (2008a). Externally commercializing technology assets: An examination of different process stages. Journal of Business Venturing, 23(4), 445-464. 
LICHTENTHALER, U. (2008b). Leveraging technology assets in the presence of markets for knowledge. European Management Journal, 26(2), I22-I34.

LICHTENTHALER, U. (2008c). Open innovation and the importance of actively managing outward technology transfer. International Journal of Technology Intelligence and Planning, 4(4), 466-479.

LICHTENTHALER, U. 2008d. Open innovation in practice: An analysis of strategic approaches to technology transactions. IEEE Transactions on Engineering Management, 55(I), I48-157.

LICHTENTHALER, U., Ernst, H. 2008a. Innovation Intermediaries: Why Internet Marketplaces for Technology Have Not Yet Met the Expectations. Creativity and Innovation Management, 17(I), 14-25.

LICHTENTHALER, U., Ernst, H. (2008b). Intermediary services in the markets for technology: Organizational antecedents and performance consequences. Organization Studies, 29(7), 1003-1035.

LICHTENTHALER, U., Lichtenthaler, E., Frishammar, J. (2008). Technology commercialization intelligence: Organizational antecedents and performance consequences. Technological Forecasting and Social Change.

MORGAN, L., Finnegan, P. (2008). Deciding on Open Innovation: An Exploration of How Firms Create and Capture Value with Open Source Software. In G. Leon, A. Bernandos, J. Casar, K. Kautz, \& J. DeGross (Eds.), Open IT - Based Innovation: Moving Towards Cooperative IT Transfer and Knowledge Diffusion, 287, 229-246. Boston: Springer.

MOWERY, D. C. (2009). Plus ça change: Industrial RD in the third industrial revolution. Industrial and Corporate Change, 18(I): I-50.

OECD (2008). Open Innovation in global networks. OECD publications.

PENIN, J., Wack, J. P. (2008). Research tool patents and free-libre biotechnology: A suggested unified framework. Research Policy, 37(10), 1909-1921.

PERKMANN, M., Walsh, K. 2007. University-industry relationships and open innovation: Towards a research agenda. International Journal of Management Reviews, 9(4), 259-280.

PILLER, F. T., Walcher, D. (2006). Toolkits for idea competitions: a novel method to integrate users in new product development. R\&D Management, 36, 307-3I8.

PRAHALAD, C. K., Ramaswamy, V. 2000. Co-opting Customer Competence. Harvard Business Review (I), 7987.

ROTHWELL, R. (1992). Successful industrial innovation: critical success factors for the 1990s. R\&D Management, 22(3): $221-239$.

SANDULLI, F. D., Chesbrough, H. (2009). The Two Sides of Open Business Models. Universia Business Review (22), 12-39.

SAWNEY, M., Prandelli, E. (2000). Communities of creation: Managing distributed innovation in turbulent markets. California Management Review, 42, 24-54.

SLOWINSKI, G., Hummel, E., Gupta, A., Gilmont, E. R. (2009). Effective practices for sourcing innovation. Research Technology Management, 52(I), 27-34.

SLOWINSKI, G., Zerby, K. W. (2008). Protecting IP in collaborative research, Research Technology Management, 5I, 58-65.

TERWIESCH, C., Xu, Y. (2008). Innovation contests, open innovation, and multiagent problem solving. Management Science, 54(9), 1529-1543.

TETHER, B. S., Tajar, A. (2008). Beyond industryuniversity links: Sourcing knowledge for innovation from consultants, private research organizations and the public science-base. Research Policy, 37(6-7), 1079-1095.

VON HIPPEL, E. (2005). Democratizing innovation, Cambridge, Mass., MIT Press.

WAGUESPACK, D. M., Fleming, L. (2009). Scanning the Commons? Evidence on the Benefits to Startups Participating in Open Standards Development. Management Science, 55(2), 210-223. 
WEST, J., Gallagher, S. (2007). Patterns of Open innovation in Open Source Software. In: Chesbrough, H. V. Open innovation - researching a new paradigm. New York, NY, Oxford University Press.

WEST, J., Lakhani, K. R. (2008). Getting Clear About Communities in Open Innovation. Industry and Innovation, I5(2), 223-23I.

VANHAVERBEKE, W., Van de Vrande, V., Chesbrough, H. (2008). Understanding the Advantages of Open Innovation Practices in Corporate Venturing in Terms of Real Options. Creativity and Innovation Management, I7(4), 25I258.

WINCENT, J., Anokhin, S., Boter, H. (2009). Network board continuity and effectiveness of open innovation in Swedish strategic small-firm networks. R\&D Management, 39(I), 55-67.

YOUNG, B., Hewitt-Dundas, N., Roper, S. (2008). Intellectual Property management in publicly funded R\&D centers - A comparison of university-based and companybased research centers. Technovation, 28(8), 473-484. 


\section{Appendix A}

The coding scheme and the coding manual used for the content analysis of the literature are presented here.

\section{Coding Scheme}

This is the coding scheme used for the coding analysis as described in Chapter 3: Methodology. The Coding scheme includes the open coding as well.

\begin{tabular}{l}
\hline Research dimension \\
\hline Article Title \\
Author \\
Journal \\
New Title \\
Match with previous categories \\
Which previous category does it match? \\
Recommendations for managers \\
What kind of recommendations \\
Suggestions for future research \\
New Title \\
Important Words
\end{tabular}

\section{Coding Manual}

This is the coding manual used for the coding analysis as described in Chapter 3: Methodology.

\begin{tabular}{ll}
\hline Research dimension & Answer \\
\hline Article Title & The title \\
Author & The name(s) of the author(s) \\
Journal & The journal \\
Research Design & I.Case Study \\
& 2. Literature Review \\
& 3. Survey/Questionnaires \\
& 4. Conceptual Paper \\
& 5. Other \\
Match with previous categories & I. Yes \\
Which previous category does & 2. No \\
match? & I. Exploring the notion of Open Innovation \\
& 2. Business Models \\
& 3. Organizational Design and Boundaries of the Firm
\end{tabular}




\begin{tabular}{ll}
\hline & 4. Leadership and Culture \\
& 5. Tools and Technologies \\
& 6. IP, Patenting and Appropriation \\
& 7. Industrial Dynamics and Manufacturing \\
Recommendations for managers & I. Yes \\
What kind of recommendations & 2. No \\
Suggestions for future research & OPEN CODING \\
& I. Type of subject and OPEN CODING \\
New Title & OPEN CODING \\
Important Words & OPEN CODING \\
\hline
\end{tabular}

This table is a part of the coding manual and explains how the question: "Which previous category does it match?" will be answered in the coding scheme. The table makes part of the coding manual, however due to its size it is not incorporated in the coding manual but it is presented separately.

\begin{tabular}{|c|c|c|}
\hline $\begin{array}{l}\text { Coding } \\
\text { Number }\end{array}$ & Category & Words and Phrases \\
\hline I & $\begin{array}{l}\text { Exploring the notion of Open } \\
\text { Innovation }\end{array}$ & $\begin{array}{l}\text { Open Innovation, concept, openness, open business model, } \\
\text { inbound innovation, outbound innovation, exploration, exploitation } \\
\text { and others }\end{array}$ \\
\hline 2 & Business Models & $\begin{array}{l}\text { Business model, create value, capture value, licensing, spinoff, } \\
\text { outsourcing, partnership, alliance, collaboration }\end{array}$ \\
\hline 3 & $\begin{array}{l}\text { Organizational Design } \\
\text { Boundaries of the Firm }\end{array}$ & $\begin{array}{l}\text { Organizational design, boundaries, outside the firm, external assets, } \\
\text { external knowledge, structures, mechanisms, organizational set-up }\end{array}$ \\
\hline 4 & Leadership and Culture & $\begin{array}{l}\text { Leadership, project leader, culture, mindset, relationship(s), } \\
\text { relationship management, trust, control, respect, manager(s) }\end{array}$ \\
\hline 5 & Tools and Technologies & $\begin{array}{l}\text { Tools, technologies, internet tools, solution providers, customers, } \\
\text { interface, coordinating tools or technologies, liberating tools or } \\
\text { technologies, idea competition, customer creativity, } \\
\text { allowing/including tools or technologies, sources of ideas, customer } \\
\text { interaction, integrate customers, collective invention, avatar, virtual } \\
\text { world, co-creation, lead users }\end{array}$ \\
\hline 6 & IP, Patenting and Appropriation & $\begin{array}{l}\text { IP, intellectual property, IPR, property rights, intellectual assets, } \\
\text { protection of IP, technology assets, free revealing, secrecy, selective } \\
\text { revealing, appropriability, regime }\end{array}$ \\
\hline 7 & $\begin{array}{l}\text { Industrial Dynamics } \\
\text { Manufacturing }\end{array}$ & $\begin{array}{l}\text { Industry, evolutionary economics, economics, innovation systems, } \\
\text { technological regime, regime regional innovation system(s), } \\
\text { cluster(s), regional, mega-centers, manufacturing, lean production, } \\
\text { competitiveness, technology policy, policy(ies), economic } \\
\text { development }\end{array}$ \\
\hline
\end{tabular}

